\title{
When the Killing's Done
}

\author{
T. Coreghessan Boyle. 2011. Viking Press, New York, NY. Pp. 384. ISBN10: 0143120395. ISBN13: 978-0143120391
}

\author{
Reviewed by Torben C. Rick
}

Reviewer Address: Program in Human Ecology and Archaeobiology, Department of Anthropology, National Museum of Natural History, Smithsonian Institution, Washington D.C. 20013-7012

rickt@si.edu

Received: February $20^{\text {th }} 2012$

Volume 3:16-17

Published: March 14 2012

(C) 2012 Society of Ethnobiology

A review of a novel is not what you generally expect to read in Ethnobiology Letters, but When the Killing's Done brings important topics-namely invasive species and conservation biology-into the heart of popular culture. Using examples of invasive species eradication on California's Channel Islands and tensions between conservation biologists and animal rights activists, Boyle thrusts human environmental interactions, island ecology, and restoration ecology into a dramatic narrative (see a cinematic trailer for the book here: http://www.youtube.com/watch?v $=$ ryFvrjhI3Pk). This book has all the makings of a good novel from death to shipwrecks and dramatic chases. Unlike most novels, these occur because of conflict and disagreement over how best to manage invasive species, the ecological problems invasive species cause, and the concerns of animal rights activists about the fate of invasive species facing eradication. Although the book is a work of fiction, its core elements are based on real events, including the eradication of introduced black rats (Rattus rattus) from Anacapa Island by the National Park Service (NPS) in 2001-2002 and wild pigs (Sus scrofa) from Santa Cruz Island by the NPS and the Nature Conservancy (TNC) in 2005-2007.

The book begins with a brief historical account of a shipwreck that left a fictitious NPS biologist Alma Takesue's grandmother shipwrecked on Anacapa Island decades ago, and already invaded by rats. The book then jumps ahead to the present day with Takesue presenting at a public hearing on the NPS proposal to eradicate rats from Anacapa because of the major impact they are having on island birds, deer mice, and other species. The writing is vivid and descriptions of the lecture hall, parking lot, and landscape will be easily recognizable to anyone familiar with the region. At this hearing we meet Dave LaJoy, an arrogant, well to do, animal rights activist who deeply opposes rat eradication, asking Takesue at one point, "And who exactly was it appointed you god, lady?” (p. 64). Here LaJoy makes an important point that is at the core of conservation biology and one that many archaeologists, anthropologists, historians, ecologists, and other researchers are working to understand. LaJoy asks, "Those rats have been there for a hundred and fifty years!...What's your baseline? A hundred years ago? A thousand? Ten thousand?" (p. 63). This is a key question for restoration ecologists: what are the baselines and targets that should be used for restoration and management, especially since ecosystems change over time (Lyman 2006; Jackson et al. 2011)? More simply, LaJoy asks, What is natural? What is anthropogenic? Why should we care?

LaJoy ends up sailing with two others to Anacapa Island during rat eradication to spread vitamin $\mathrm{K}$, an antidote to the poison being used to kill the rats. After dealing with the rat issue and additional details of LaJoy and Takesue's life, the book focuses on pig eradication on Santa Cruz Island. LaJoy and his group find themselves working to thwart the eradication of pigs, with their efforts spiraling downhill with exciting plot twists.

Through all of the excitement and fantasy, Boyle provides an important account of modern conservation biology and human environmental interactions. Often called a North American Galapagos, California's Channel Islands are home to numerous endemic mammals, land birds, and rare plants, many of which are the subject of ongoing conservation and restoration efforts by the NPS, TNC, US Navy, Catalina Island Conservancy, and other groups (Schoenherr et al. 1999). While Boyle correctly has LaJoy ask about baselines for ecological restoration and conservation, we are later led to believe that the islands were largely 
free from human influence prior to the rapid alteration of the $19^{\text {th }}$ and $20^{\text {th }}$ centuries when commercial ranching operations and other groups introduced numerous animal and plant species and dramatically altered island ecosystems. Unfortunately, the book unwittingly takes a view common among some researchers and members of the public by failing to discuss the legacy of long-term influence that Native Americans had on island ecology during their 13,000 year history on the Channel Islands (Erlandson and Rick 2010). It is hard to fault Boyle here, but this is a challenge for archaeologists, historical ecologists, and other researchers as we work to more firmly place our research on ancient and modern human environmental interactions into broader scientific, public, and popular discourse on conservation.

When the Killing's Done offers many items for reflection. What is natural or pristine? Are humans part of or separate from nature? Given deep time (centuries, millennia, or more) interactions between people and the environment around the world, how do we best manage earth's ecosystems for the future? Should the goal be to erase people from the system and harken back to pre-human environments, such as the Pleistocene in the Americas and Australia, but as early as the Miocene in Africa? Is there middle ground, where people are not divorced from the ecosystems they inhabited for centuries, millennia, or more and modern management efforts account for different temporal ecological baselines? What about animal rights concerns and the eradication of invasive species? There are no clear answers to these questions, but there is need for continued collaboration between social scientists, ecologists, biologists, resource managers, and others. Ethnobiologists are at the forefront of this endeavor (Lepofsky 2009; Wolverton et al. 2011), but we need to continue to transcend disciplinary boundaries and confront difficult questions about human environmental relationships (past and present). As ethnobiology demonstrates, creating a sharp separation between the natural and anthropogenic worlds is problematic on many levels and is a topic worthy of scientific discussion, as well as public and popular dialogue. Boyle's book demonstrates that these issues are making their way into popular culture.

When the Killing's Done is worth a read and discussion with friends, colleagues, and students. The book is not the first popular medium to explore conservation biology and human environmental interactions, and it will not be the last. A key for ethnobiologists and other researchers is to help shape popular discourse and continue to demonstrate the importance of our deep temporal and cross-cultural perspectives for managing contemporary ecosystems and organisms.

\section{References Cited}

Erlandson, J. M. and T. C. Rick. 2010. Archaeology Meets Marine Ecology: The Antiquity of Maritime Cultures and Human Impacts on Marine Fisheries and Ecosystems. Annual Review of Marine Science 2:231-251.

Jackson, J. B. C., K. A. Alexander and E. Sala, eds. 2011. Shifting Baselines: The Past and the Future of Ocean Fisheries. Island Press, New York, NY.

Lepofsky, D. 2009. The Past, Present, and Future of Traditional Resource and Environmental Management. Journal of Ethnobiology 29:161-166.

Lyman, R. L. 2006. Paleozoology in the Service of Conservation Biology. Evolutionary Anthropology 15:1119.

Schoenherr, A. A., R. C. Feldmath and M. J. Emerson. 1999. Natural History of the Islands of California. University of California Press, Berkeley, CA.

Wolverton, S., C. R. Randklev and A. Barker. 2011. Ethnobiology as a Bridge Between Science and Ethics: An Applied Paleozoological Perspective. In Ethnobiology, edited by E. N. Anderson, D. M. Pearsall, E. S. Hunn and N. J. Turner, pp. 115-132. WileyBlackwell, Hoboken, NJ. 